\title{
Blood serum protein in periparturient goats supplemented with various forms of zinc
}

\author{
Lenka Kudělková ${ }^{1}$, Leoš Pavlata², Alena Pechová ${ }^{2}$, Jaroslav Filípek ${ }^{4}$ \\ ${ }^{1}$ University of Veterinary and Pharmaceutical Sciences Brno, Faculty of Veterinary Hygiene and Ecology, \\ Department of Animal Husbandry and Animal Hygiene, Brno, Czech Republic \\ ${ }^{2}$ Mendel University in Brno, Faculty of AgriSciences, Department of Animal Nutrition and Forage Production, \\ Brno, Czech Republic \\ ${ }^{3}$ University of Veterinary and Pharmaceutical Sciences Brno, Faculty of Veterinary Hygiene and Ecology, \\ Department of Animal Protection, Welfare and Behaviour, ${ }^{4}$ Faculty of Veterinary Medicine, \\ Large Animal Clinical Laboratory, Brno, Czech Republic
}

Received June 21, 2016

Accepted December 2, 2016

\begin{abstract}
The aim of the study was to compare the contents of individual protein fractions determined by electrophoresis in the blood serum of 32 periparturient goats supplemented with various forms of zinc $(\mathrm{Zn})$. Goats were divided into four groups: Group A was a control (without $\mathrm{Zn}$ supplementation). The remaining three groups (B, C, D) were supplemented with $\mathrm{Zn}$ in various forms. Group B was supplemented with zinc oxide, Group C with zinc lactate, and Group D with zinc chelate. Individual protein fractions (albumins, $\alpha 1, \alpha 2, \beta 1, \beta 2$ a $\gamma$-globulins) were identified by electrophoretic analysis. All supplemented groups showed the trend of a positive influence of $\mathrm{Zn}$ on $\gamma \mathrm{G}$ fractions in the serum protein of the goats; this tendency was significant only in Group C. Moreover, Group C had significantly the highest total protein values and albumins. The results indicated that a feed enriched with various forms of $\mathrm{Zn}$ had a significant influence on the quantity of individual protein fractions of blood serum. Our results provide new knowledge on the values of individual protein fractions of serum goats and should be taken into consideration when interpreting the serum protein profile with regard to periparturient goats. Furthermore, we showed the possible positive or negative effects on the values of individual fraction on serum proteins with organic and inorganic zinc form supplemented rich in diet.
\end{abstract}

Goats, gel electrophoresis, protein fractions, organic zinc, inorganic zinc

Zinc research has received considerable attention both in human and veterinary medicine. The supplements most commonly used are inorganic zinc (oxide, sulphate) or organic zinc in the chelated form (Pechova et al. 2009; Strnadova et al. 2011). Zinc is one of the essential microelements that influence metabolism, the immune system and overall health condition (Pavlata et al. 2011). In animal organism, zinc works as an activator of more than 200 enzymes and therefore, its deficiency has a negative impact on the organism as a whole (Evans and Halliwell 2001). Due to the multiple mechanisms of zinc action, we can presume its role in the synthesis of serum proteins that can be identified by the method described below. Due to the many biological functions of microelements and because they are transferred through the placenta to the foetus, and also to colostrum and milk, sufficient saturation of pregnant animals with microelements is very important to meet the needs of their young (Pavlata et al. 2005).

Although electrophoresis has long been used as a separation process and chemical analysis, in veterinary medicine this method has been used in relation to farm animals only for the last 10 years. During electrophoresis, $\alpha$ - and $\beta$-globulins are often separated into $\alpha 1-, \alpha 2-$, and $\beta 1$-, $\beta 2$-globulin fractions (Janku et al. 2011). Each classical zone (globulin fraction) contains two or more proteins (Tothova et al.2013), e.g. $\alpha$-globulins include serum amyloid A, ceruloplasmin, and haptoglobin. Beta-globulins include transferrin, fibrinogen

Address for correspondence:

MVDr. Lenka Kudělková, Ph.D

Department of Animal Husbandry and Animal Hygiene

Faculty of Veterinary Hygiene and Ecology

University of Veterinary and Pharmaceutical Sciences Brno

Palackého tř. 1946/1, 61242 Brno, Czech Republic 
and complement components. Gamma-globulins include individual immunoglobulin classes. In veterinary medicine, electrophoresis is predominantly used to support diagnoses of hepatic, endocrine, and infectious diseases, to differentiate between acute or chronic states of diseases, and to diagnose inflammation in small animals, goats, calves, and horses (Sevelius and Anderson 1995; Santarosa et al. 2005; Thomas 2006; Eckersall 2008; Diogenes et al. 2010; Fonteque et al. 2010; Piccione et al. 2011b; Tothova et al. $2012 b$ ). Individual protein fractions, or blood serum proteins, have different functions and their identification is used also as a diagnostic tool. Many of these proteins are socalled acute phase proteins. Acute phase proteins (APP) are reactants synthesized during an acute phase response to several stimuli such as infection, inflammation, stress, trauma, tissue damage or neoplasia (Pyorala 2000; Murata et al. 2004; Petersen et al. 2004; Tothova and Kovac 2009; Tothova et al. 2014). Moreover, several physiological factors affect serum protein concentrations, including the species and breed, age, hormones, sex, pregnancy, colostrum and milk intake, lactation, temperature, season and seasonal rhythms (Shaffer et al. 1981; Krajnicakova et al. 2003; Batavani et al. 2006; Thomas 2006; Balikci et al. 2007; Eckersall 2008; Piccione et al. 2010; Janku et al. 2011; Piccione et al. 2011a; Piccione et al. 2012; Nagy et al. 2014a; Nagy et al. 2014b; Tothova et al. 2014; Nagy et al. 2015). In addition, serum protein concentrations are affected also by the storage duration of blood serum samples and the refrigerator temperatures (Tothova et al. 2012a).

The objective of the presented paper was to describe and expand on the knowledge of serum proteins using electrophoresis in healthy periparturient goats supplemented with various forms of zinc.

\section{Materials and Methods}

Animals and Feeding

The experiment was performed on 32 breeding white shorthaired goats in their second lactation. A part of our results (the control group only) was published in the study by Janku et al. (2011). Goats were stabled on straw litter and fed twice a day a complementary diet consisting of barley (30\%), wheat (20\%), alfalfa meal $(18 \%)$, sunflower extracted unpeeled groats $(10 \%)$, wheat bran $(10 \%)$, maize $(5 \%)$, malt sprouts $(5 \%)$, dicalcium phosphate $(1.1 \%)$, sodium chloride $(0.7 \%)$, and calcium carbonate $(0.2 \%)$. Daily dose of this diet $(0.6 \mathrm{~kg}$ per animal before parturition, $1.0 \mathrm{~kg}$ per animal after parturition) was fed in combination with hay, water and $\mathrm{NaCl}$ (lick) ad libitum. For the experiment, the goats were divided into four groups. The first group was used as a control group (Group A, $\mathrm{n}=8$ ). The supplementary diet for goats in Group A was not enriched with $\mathrm{Zn}$ and contained $21 \mathrm{mg} \mathrm{Zn/kg}$ of dry matter. The other three groups (B, C, and D) were supplemented with $\mathrm{Zn}$ in various forms and addressed the physiological requirements of goats. Supplementary diet included inorganic $\mathrm{Zn}$ in the form of zinc oxide $(\mathrm{ZnO})$ for Group B $(\mathrm{n}=8)$, $\mathrm{Zn}$ lactate for Group C ( $\mathrm{n}=8$, zinc lactate trihydrate, Zinc chelate, Agrobac, Czech Republic), and Zn chelate for Group D ( $\mathrm{n}=8$, Bioplex Zn, Alltech, USA). The zinc concentration in the feed mixtures for Groups B, C, and D was $60 \mathrm{mg} / \mathrm{kg}$ of dry matter. The mean Zn content in hay was 11.0 $\pm 4.2 \mathrm{mg} / \mathrm{kg}$ of dry matter. Goats received Zn-enriched diet 2 months before the anticipated parturition and all animals were also fed a complementary diet at the same time. We calculated the zinc intake in individual groups on the basis of table values for dry matter intake, the zinc concentration in hay $(11 \mathrm{mg} / \mathrm{kg})$, and the doses of granules. The zinc intake was $28 \mathrm{mg} /$ day in late gestation and $36 \mathrm{mg} /$ day in early lactation in Group A. The zinc intake was $52 \mathrm{mg}$ /day in late gestation and $75 \mathrm{mg} /$ day in early lactation in Groups B, C, and D. The zinc intake in Group A was insufficient; in Groups B, C, and D it corresponded with NRC (2007), where is recommended for goats in late gestation $46 \mathrm{mg}$ /day (single kid) or $67 \mathrm{mg}$ /day (twins) and in early lactation $53 \mathrm{mg} /$ day (single kid) or $82 \mathrm{mg}$ /day (twins).

The animals were examined and found to be healthy, showing no signs of disease. Spontaneous parturitions were controlled by a veterinarian. Puerperium was physiological in all animals.

The experiment took place in accredited stables of the Ruminant and Swine Clinic of the University of Veterinary and Pharmaceutical Sciences Brno and was approved by the Animal Welfare Committee of the University of Veterinary and Pharmaceutical Sciences Brno.

\section{Sampling and laboratory tests}

First blood samples were taken before the administration of feed supplemented with $\mathrm{Zn}$ in various forms. The first blood samples served to obtain the initial total protein (TP) and albumin concentrations and to further divide animals into four groups so that their average TP and albumin values were balanced. Other blood samples were 
taken (in the morning) by direct puncture of v. jugularis three and two weeks before the anticipated parturition, on the parturition day, and on days 7 and 28 after the parturition. After the samples were precipitated, they were centrifuged at $1,500 \mathrm{~g}$ for $10 \mathrm{~min}$. The serum obtained in this way was kept frozen at $-20{ }^{\circ} \mathrm{C}$ until examined.

Individual protein fractions were manually identified from serum by Hydragel Protein K20 (Sebia, France) on $1 \%$ buffered agarose gel at $\mathrm{pH} 8.6$, according to the the manufacturer's instructions. Serum samples (10 $\mu 1)$ were applied in a horizontal arrangement, with 7 samples on a plate. The electrophoretic migration was performed for $22 \mathrm{~min}$ at initial $120 \mathrm{~mA}$ and constant $90 \mathrm{~V}$. Serum proteins were separated on individual protein fractions into albumins, $\alpha 1, \alpha 2, \beta 1, \beta 2$ and $\gamma$-globulins $(\gamma \mathrm{G})$ (in the direction from the positive pole). The electrophoretogram (serum protein fractions) was evaluated by densitometry at $570 \mathrm{~nm}$ wavelength using DVSE (densitometer for electrophoresis gels) manufactured by Sebia and automatically converted into optical density, presented as a graph. Percentage shares of individual protein fractions were converted from total protein (TP) values to (g/l) values. Total protein was determined quantitatively by Bio Vendor set according the manuscript (BioVendor, Czech Republic). Total protein was identified photometrically at a $540 \mathrm{~nm}$ wavelength by the biuret method using the Cobas Mira device (Roche, Switzerland).

\section{Statistical methods}

Basic statistical characteristics of measured values were processed using Microsoft Excel Software. Statistical differences among groups was done by one-way analysis of variance (ANOVA) and $t$-test. The results are presented as means with standard deviation. Time effect testing was analysed using Tukey's HSD test.

\section{Results}

First samples taken before the examined goats were fed the $\mathrm{Zn}$-supplemented diets showed that all groups had similar values of total protein (TP) and albumins. The mean total protein (TP) concentration was $70.7 \pm 3.7 \mathrm{~g} / \mathrm{l}$ in the control Group A; $71.4 \pm 5.0 \mathrm{~g} / \mathrm{l}$ in Group B; $71.3 \pm 4.4 \mathrm{~g} / \mathrm{l}$ in Group C; and $70.9 \pm 3.0 \mathrm{~g} / \mathrm{l}$ in Group D. The mean albumin concentration was $37.8 \pm 3.2 \mathrm{~g} / \mathrm{l}$ in Group A; $38.4 \pm 1.4 \mathrm{~g} / \mathrm{l}$ in Group B; $38.9 \pm 1.7 \mathrm{~g} / \mathrm{l}$ in Group C; and $38.9 \pm 1.2 \mathrm{~g} / \mathrm{l}$ in Group D. Results (mean \pm standard deviation) of individual protein fractions are presented in Table 1. The highest concentrations of TP and albumin during the whole experiment were measured in Group C, which was supplemented with the lactate form of zinc. Some differences were found to be significant (Table 1). As for globulin fractions, an evident increase of $\alpha 1$ fraction was observed when supplementing the diet with zinc oxide (in contrast to Groups A and D). On the contrary, $\alpha 2$ fraction was not affected by $\mathrm{Zn}$ supplementation at all. Regarding $\beta$ fraction, higher concentration values were sporadically found in Group D (Table 1). In groups supplemented with zinc (compared to the control group), we observed a tendency to increased $\gamma \mathrm{G}$ concentrations. However, only in the final blood sample taken 28 days after parturition, the difference between the control group and Group $\mathrm{C}$ was significant. The obtained results show that the concentration of individual indicators change (except for $\alpha 1$ globulins) significantly with the stage of reproduction and lactation (Table 1).

\section{Discussion}

The mean value of the total protein (TP) concentration observed in all experimental groups in this study ranged between 60.1 to $75.2 \mathrm{~g} / \mathrm{l}$. Before and on the parturition day, TP was at the lower physiological range limit (or even slightly below it) reported in other studies: $70.0 \pm 5.86 \mathrm{~g} / \mathrm{l}$ (Santarosa et al. 2005); 62.0-79.0 g/l (Matthews 2009); $72.2 \pm 6.4 \mathrm{~g} / \mathrm{l}$ (Alberghina et al. 2010); $70.7 \pm 1.1 \mathrm{~g} / \mathrm{l}$ (Diogenes et al. 2010). The TP concentration started to increase gradually from Day 7 after parturition, with the highest mean concentration measured on Day 28 after the parturition. Group C (zinc lactate) showed the highest TP rise due to an increase in albumin and $\gamma \mathrm{G}$ globulin values. Similar changes in TP values in the goats' blood serum in puerperium to those found in our study were also reported by Krajnicakova et al. (2003) who observed TP of $65.48 \pm 3.15 \mathrm{~g} / \mathrm{l}$ on the first day after parturition, whereas 40 days after parturition the TP values were $71.79 \pm$ $1.55 \mathrm{~g} / 1$. It is likely that relatively low TP values obtained 3 weeks before parturition were 
affected by the fact that goats were already preparing for parturition and were undergoing many immunological changes typical for this period.

Albumin values changed significantly $(P<0.01)$ during the study as well except for Group D. Although the mean value was gradually increasing from the parturition day to day 28 after parturition, it remained mostly within the reported physiological range: $37.0 \pm 5.5 \mathrm{~g} / \mathrm{l}$ (Santarosa et al. 2005); 28.0-43.0 g/l (Matthews 2009); $31.8 \pm 4.0 \mathrm{~g} / \mathrm{l}$ (Alberghina et al. 2010); $48.0 \pm 1.0 \mathrm{~g} / \mathrm{l}$ (Diogenes et al. 2010). The highest albumin concentrations of all the examined groups were also observed in Group C (zinc lactate). Higher albumin values (but still within the physiological range) found in Group C (zinc

Table 1. Concentrations (mean \pm standard deviation) of total protein and individual serum protein fractions ( $\mathrm{g} / \mathrm{l})$ identified by electrophoresis in periparturient goats (A - control group, B - group supplemented with zinc oxide, C group supplemented with zinc lactate, and D - group supplemented with zinc chelate).

\begin{tabular}{|c|c|c|c|c|c|c|}
\hline & Group & $\begin{array}{c}3 \text { weeks } \\
\text { before parturition }\end{array}$ & $\begin{array}{c}2 \text { weeks } \\
\text { before parturition }\end{array}$ & $\begin{array}{c}\text { Day of } \\
\text { parturition }\end{array}$ & $\begin{array}{l}7 \text { days after } \\
\text { parturition }\end{array}$ & $\begin{array}{c}28 \text { days after } \\
\text { parturition }\end{array}$ \\
\hline \multirow[t]{8}{*}{ TP } & A & $60.8 \pm 3.8$ & $60.9 \pm 3.9$ & $60.6 \pm 4.3$ & $65.1 \pm 3.2$ & $71.3 \pm 2.4$ \\
\hline & & Z & $\mathrm{a}, \mathrm{Y}$ & $\mathrm{X}$ & W & $\mathrm{A}, \mathrm{Z}, \mathrm{Y}, \mathrm{X}, \mathrm{W}$ \\
\hline & B & $60.1 \pm 4.7$ & $60.4 \pm 2.6$ & $64.6 \pm 2.9$ & $66.5 \pm 4.9$ & $71.3 \pm 2.4$ \\
\hline & & Z & $b, Y$ & $\mathrm{x}$ & & $\mathrm{Z}, \mathrm{Y}, \mathrm{x}$ \\
\hline & $\mathrm{C}$ & $63.9 \pm 2.9$ & $65.2 \pm 3.2$ & $64.4 \pm 3.0$ & $68.9 \pm 3.2$ & $75.2 \pm 2.2$ \\
\hline & & $\mathrm{Z}, \mathrm{z}$ & $\mathrm{a}, \mathrm{b}, \mathrm{Y}$ & $\mathrm{X}$ & $\mathrm{W}, \mathrm{z}$ & $\mathrm{A}, \mathrm{Z}, \mathrm{Y}, \mathrm{X}, \mathrm{W}$ \\
\hline & D & $61.4 \pm 2.3$ & $63.0 \pm 2.3$ & $63.9 \pm 8.7$ & $68.4 \pm 6.0$ & $71.9 \pm 4.7$ \\
\hline & & $\mathrm{z}$ & $\mathrm{y}$ & & & $\mathrm{z}, \mathrm{y}$ \\
\hline \multirow[t]{8}{*}{ Alb } & A & $36.7 \pm 1.7$ & $37.1 \pm 2.3$ & $37.4 \pm 2.9$ & $39.0 \pm 2.0$ & $42.7 \pm 1.0$ \\
\hline & & Z & $\mathrm{a}, \mathrm{Y}$ & $\mathrm{X}$ & $\mathrm{a}, \mathrm{W}$ & Z, Y, X, W \\
\hline & B & $35.0 \pm 2.4$ & $35.0 \pm 1.0$ & $37.0 \pm 2.5$ & $38.1 \pm 2.4$ & $41.3 \pm 2.0$ \\
\hline & & $\mathrm{a}, \mathrm{Z}$ & $\mathrm{a}, \mathrm{B}, \mathrm{C}, \mathrm{Y}$ & $\mathrm{x}$ & $\mathrm{b}$ & $\mathrm{a}, \mathrm{Z}, \mathrm{Y}, \mathrm{x}$ \\
\hline & $\mathrm{C}$ & $38.2 \pm 1.6$ & $39.3 \pm 2.7$ & $39.7 \pm 1.8$ & $41.5 \pm 1.9$ & $44.8 \pm 2.4$ \\
\hline & & $\mathrm{a}, \mathrm{Z}$ & $\mathrm{B}, \mathrm{Y}$ & $\mathrm{X}$ & $\mathrm{a}, \mathrm{b}$ & a, Z, Y, X \\
\hline & D & $37.3 \pm 1.9$ & $37.4 \pm 1.5$ & $37.4 \pm 8.6$ & $38.5 \pm 6.8$ & $42.5 \pm 5.3$ \\
\hline & & & $\mathrm{C}$ & & & \\
\hline \multirow[t]{7}{*}{$\alpha 1$} & A & $3.5 \pm 0.5$ & $3.5 \pm 0.4$ & $3.5 \pm 0.6$ & $3.9 \pm 0.7$ & $3.3 \pm 0.6$ \\
\hline & & A & A & A & $\mathrm{a}$ & A \\
\hline & B & $4.4 \pm 0.5$ & $4.4 \pm 0.5$ & $4.6 \pm 0.6$ & $4.8 \pm 0.6$ & $4.8 \pm 0.7$ \\
\hline & & $\mathrm{A}, \mathrm{b}$ & $\mathrm{A}, \mathrm{b}$ & A, B & a & $\mathrm{A}, \mathrm{b}$ \\
\hline & $\mathrm{C}$ & $3.3 \pm 0.8$ & $3.4 \pm 0.8$ & $3.4 \pm 1.0$ & $3.6 \pm 0.9$ & $3.8 \pm 1.0$ \\
\hline & D & $3.6 \pm 0.6$ & $3.9 \pm 0.7$ & $3.7 \pm 0.9$ & $3.9 \pm 0.7$ & $3.3 \pm 0.6$ \\
\hline & & $\mathrm{b}$ & $\mathrm{b}$ & $\mathrm{B}$ & & $\mathrm{b}$ \\
\hline \multirow[t]{8}{*}{$\alpha 2$} & A & $3.1 \pm 0.5$ & $3.2 \pm 0.4$ & $3.4 \pm 0.5$ & $3.4 \pm 0.6$ & $4.1 \pm 0.8$ \\
\hline & & $\mathrm{z}$ & $\mathrm{y}$ & & & $\mathrm{y}, \mathrm{z}$ \\
\hline & B & $3.0 \pm 0.4$ & $3.2 \pm 0.3$ & $3.4 \pm 0.4$ & $3.6 \pm 0.6$ & $4.1 \pm 0.5$ \\
\hline & & Z & Y & $\mathrm{x}$ & & $\mathrm{Z}, \mathrm{Y}, \mathrm{x}$ \\
\hline & $\mathrm{C}$ & $2.7 \pm 0.5$ & $2.8 \pm 0.3$ & $2.9 \pm 0.6$ & $3.1 \pm 0.6$ & $3.7 \pm 0.4$ \\
\hline & & $\mathrm{Z}$ & Y & $\mathrm{x}$ & & $\mathrm{Z}, \mathrm{Y}, \mathrm{x}$ \\
\hline & D & $3.0 \pm 0.1$ & $3.2 \pm 0.2$ & $3.6 \pm 0.3$ & $3.9 \pm 0.5$ & $4.1 \pm 0.6$ \\
\hline & & $\mathrm{Z}, \mathrm{W}$ & $\mathrm{Y}, \mathrm{w}$ & & $\mathrm{W}, \mathrm{w}$ & $\mathrm{Z}, \mathrm{Y}$ \\
\hline
\end{tabular}


Table 1. Concentrations (mean \pm standard deviation) of total protein and individual serum protein fractions $(\mathrm{g} / \mathrm{l})$ identified by electrophoresis in periparturient goats (A - control group, B - group supplemented with zinc oxide, C group supplemented with zinc lactate, and D - group supplemented with zinc chelate).

\begin{tabular}{|c|c|c|c|c|c|c|}
\hline & Groups & $\begin{array}{c}3 \text { weeks } \\
\text { before parturition }\end{array}$ & $\begin{array}{c}2 \text { weeks } \\
\text { before parturition }\end{array}$ & $\begin{array}{c}\text { Day of } \\
\text { parturition }\end{array}$ & $\begin{array}{l}7 \text { days after } \\
\text { parturition }\end{array}$ & $\begin{array}{c}28 \text { days after } \\
\text { parturition }\end{array}$ \\
\hline \multirow[t]{8}{*}{$\beta 1$} & A & $5.5 \pm 0.3$ & $5.4 \pm 0.3$ & $5.6 \pm 0.5$ & $6.4 \pm 0.8$ & $6.3 \pm 0.9$ \\
\hline & & Z & $\mathrm{Y}, \mathrm{y}$ & $\mathrm{a}, \mathrm{X}$ & $\mathrm{y}$ & $\mathrm{Z}, \mathrm{Y}, \mathrm{X}$ \\
\hline & B & $5.4 \pm 0.5$ & $5.2 \pm 0.4$ & $5.9 \pm 0.3$ & $6.1 \pm 0.6$ & $6.5 \pm 0.6$ \\
\hline & & Z & $\mathrm{Y}$ & & $a, w$ & $\mathrm{Z}, \mathrm{Y}, \mathrm{w}$ \\
\hline & $\mathrm{C}$ & $4.7 \pm 0.2$ & $4.9 \pm 0.4$ & $5.1 \pm 0.5$ & $5.8 \pm 0.3$ & $5.9 \pm 0.7$ \\
\hline & & Z & $\mathrm{Y}$ & $\mathrm{x}$ & $\mathrm{a}$ & $\mathrm{Z}, \mathrm{Y}, \mathrm{x}$ \\
\hline & $\mathrm{D}$ & $5.4 \pm 0.4$ & $5.5 \pm 0.3$ & $6.4 \pm 0.9$ & $6.9 \pm 1.2$ & $6.2 \pm 0.7$ \\
\hline & & Z & $\mathrm{y}$ & $\mathrm{a}$ & $\mathrm{Z}, \mathrm{y}$ & \\
\hline \multirow[t]{8}{*}{$\beta 2$} & A & $2.5 \pm 0.3$ & $3.2 \pm 0.4$ & $2.6 \pm 0.2$ & $2.5 \pm 0.2$ & $2.5 \pm 0.6$ \\
\hline & & & & & & $\mathrm{a}$ \\
\hline & B & $2.4 \pm 0.3$ & $2.6 \pm 0.3$ & $2.7 \pm 0.3$ & $2.3 \pm 0.6$ & $2.6 \pm 0.5$ \\
\hline & & & & & $\mathrm{a}$ & $\mathrm{b}$ \\
\hline & $\mathrm{C}$ & $2.3 \pm 0.2$ & $2.2 \pm 0.2$ & $2.3 \pm 0.1$ & $2.4 \pm 0.4$ & $2.6 \pm 0.3$ \\
\hline & & & $\mathrm{y}$ & & & $\mathrm{y}$ \\
\hline & D & $2.5 \pm 0.2$ & $2.6 \pm 0.3$ & $2.8 \pm 0.5$ & $2.9 \pm 0.6$ & $3.2 \pm 0.4$ \\
\hline & & $\mathrm{z}$ & & & a & $\mathrm{a}, \mathrm{b}, \mathrm{z}$ \\
\hline \multirow[t]{6}{*}{$\gamma \mathrm{G}$} & A & $9.5 \pm 2.6$ & $9.2 \pm 2.3$ & $8.1 \pm 1.7$ & $9.9 \pm 1.6$ & $12.3 \pm 1.9$ \\
\hline & & & & $\mathrm{X}$ & & $\mathrm{a}, \mathrm{X}$ \\
\hline & B & $9.8 \pm 3.0$ & $9.8 \pm 3.0$ & $10.2 \pm 2.7$ & $11.6 \pm 3.2$ & $12.7 \pm 4.2$ \\
\hline & $\mathrm{C}$ & $9.7 \pm 2.7$ & $9.8 \pm 2.4$ & $9.6 \pm 1.7$ & $9.5 \pm 1.4$ & $11.1 \pm 2.6$ \\
\hline & & & & & & $\mathrm{a}$ \\
\hline & D & $9.6 \pm 1.1$ & $10.3 \pm 1.5$ & $9.9 \pm 1.7$ & $11.7 \pm 1.8$ & $11.9 \pm 2.1$ \\
\hline
\end{tabular}

a, b, c, d - the same letters in one column show significance of the difference between groups $\mathrm{w}, \mathrm{x}, \mathrm{y}, \mathrm{z}$ - the same letters in one row show significance of the difference between samplings ${ }^{\mathrm{a}} P<0.05 ;{ }^{\mathrm{A}} P<0.01$

$\mathrm{TP}$ - total protein, $\alpha 1-\alpha 1$ globulins, $\alpha 2-\alpha 2$ globulins, $\beta 1-\beta 1$ globulins, $\beta 2-\beta 2$ globulins, $\gamma \mathrm{G}-\gamma \mathrm{G}$ globulins

lactate) before parturition can be considered positive as they affect the TP concentration and therefore the production of colostrum. On the contrary, lower albumin values found in Group B (zinc oxide) may represent the organisms' response to a negative stimulus (digestive tract irritation or inflammation due to the zinc oxide enriched diet), which is an opposite result compared to the study by Cernik et al. (2013).

The mean value of $\alpha 1$ globulin concentration observed in all experimental groups presented in this study ranged from $3.3 \pm 0.8$ to $4.8 \pm 0.7 \mathrm{~g} / \mathrm{l}$. The most significant change in the $\alpha 1$ globulin concentration was recorded in Group B (zinc oxide). The mean value of $\alpha 2$ globulin concentration varied from $2.7 \pm 0.5$ to $4.1 \pm 0.8 \mathrm{~g} / \mathrm{l}$. The total value of $\alpha 1$ and $\alpha 2$ globulins in all experimental groups ranged from the lowest values of $6.0 \pm 1.3 \mathrm{~g} / \mathrm{l}$ in Group C (zinc lactate) to the highest values of $8.1 \pm 1.5 \mathrm{~g} / \mathrm{l}$ in Group B. In contrast, Diogenes et al. (2010) observed a globulins fraction of $3.9 \pm 1.1 \mathrm{~g} / \mathrm{l}$. Higher values of $\alpha 1$ and $\alpha 2$ globulin fractions within all experimental groups may be associated with higher concentrations of some acute phase proteins (haptoglobin, serum amyloid A). According to the study by Krakowski and Zdzisińska (2007), Hp and SAA play an 
important role during the reproductive processes and in the reconstruction of endometrium in cattle. The mean value of $\beta 1$ globulin concentration observed in the experimental groups in this study ranged between $4.7 \pm 0.2$ to $6.9 \pm 1.2 \mathrm{~g} / \mathrm{l}$. Slightly higher concentration of $4.8 \pm 1.0 \mathrm{~g} / 1$ was reported by Diogenes et al. (2010). Comparison of the results of mean $\beta 2$ globulin concentrations observed in all experimental groups (ranging between $2.2 \pm 0.2$ to $3.2 \pm 0.4 \mathrm{~g} / \mathrm{l}$ ) with the results of $2.6 \pm 1.0 \mathrm{~g} / \mathrm{l}$ reported by Diogenes et al. (2010) shows that the values are similar.

The groups supplemented with $\mathrm{Zn}$ in various forms (B, C, D) did not show $\gamma$-globulins decrease on the parturition day. At the same time, observed $\gamma \mathrm{G}$ values in the groups supplemented with $\mathrm{Zn}(\mathrm{B}, \mathrm{C}, \mathrm{D})$ on day 28 after the parturition were higher in comparison to $\gamma \mathrm{G}$ concentrations measured in Group A. Although the measured values of $\gamma \mathrm{G}$ were found at the lower physiological range limit (or even slightly below) reported in other studies, $18.6 \pm 5.9 \mathrm{~g} / \mathrm{l}$ (Alberghina et al. 2010), and $11.5 \pm 5.0 \mathrm{~g} / \mathrm{l}$ (Diogenes et al. 2010), the results of the experiment prove a gradual increase in the $\gamma$ globulin concentrations in serum protein of the animals supplemented with various forms of zinc.

The results of our study can be compared with the results of Piccione et al. (2010) who evaluated individual protein fractions identified by electrophoresis on agarose gel in 3-4 year old healthy Girgentana goats. Piccione et al. (2010) found the following values: $72.1 \pm 1.3$ $\mathrm{g} / \mathrm{l}$ of TP, $32.3 \pm 0.8(\mathrm{~g} / \mathrm{l})$ of albumin, $6.1 \pm 0.2 \mathrm{~g} / \mathrm{l}$ of $\alpha 1$ globulins, $9.6 \pm 0.3 \mathrm{~g} / \mathrm{l}$ of $\alpha 2$ globulins, $5.6 \pm 0.4 \mathrm{~g} / \mathrm{l}$ of $\beta$ globulins and $18.4 \pm 1.6 \mathrm{~g} / \mathrm{l}$ of $\gamma \mathrm{G}$. The most significant difference between the goats from our study and the goats from the study by Piccione et al. (2010) was in TP or rather in fractions of $\gamma$-globulins. Lower values in pregnant goats and goats in puerperium should be associated with the transfer of $\gamma$-globulins to colostrum and milk. The TP concentration started to increase gradually from day 7 after the parturition. We even observed higher values on day 28 after the parturition in goats from Group C compared to those observed by Piccione et al. (2010) in their study. In contrast to our study, Piccione et al. (2010) observed the highest values of $\alpha 1$ and $\alpha 2$ globulins fraction.

The results of our study extended knowledge on the values of individual fractions of serum proteins in healthy goats and indicated that the levels of individual serum protein fractions in blood serum of the periparturient goats showed a significant dynamic response to the given supplement rich in $\mathrm{Zn}$. A significant increase in TP, albumins and $\gamma$-globulin values has been observed when administering zinc lactate. Therefore we can deduce that this organic zinc form administered in feed might positively influence protein synthesis as well as immune functions (better production of $\gamma$-globulins and concurrently also lower values of $\alpha$ and $\beta$ fractions that include acute phase proteins). On the contrary, increase in the $\alpha$ fraction and the decrease of albumin in Group B (zinc oxide) could imply some degree of damage (e.g. damage of the gastrointestinal tract) with subsequent inflammatory reaction. Therefore, further research on this topic is necessary.

\section{Acknowledgements}

Acknowledgements are due to laboratory and technical staff of the Ruminants and Swine Clinic of the Faculty of Veterinary Medicine of the University of Veterinary and Pharmaceutical Science Brno. This experimental study was elaborated under the research project MSM6215712403.

\section{References}

Alberghina D, Casella S, Vazzana I, Ferrantelli V, Giannetto C, Piccione G 2010: Analysis of serum proteins in clinically healthy goats (Capra hilus) using agarose gel electrophoresis. Vet Clin Path 3: 317-321

Balikci E, Yildiz A, Gurdogan F 2007: Blood metabolite concentrations during pregnancy and post-partum in Akkaraman ewes. Small Rum Res 67: 247-251

Batavani RA, Ansari MH, Asri S 2006: Concentrations of serum total protein and protein fractions during diestrus and pregnancy in Makuii ewes. Comp Clin Path 15: 227-230

Černík J, Pavlata L, Pechová A, Mišurová L, Jokverová O, Luňáček J, Halouzka R 2013: Effect of peroral 
supplementation of different forms of zinc on the ruminal mucosa of goat kids - a morphometric study. Acta Vet Brno 82: 399-403

Diogenes PVA, Suassuna ACD, Ahid SMM, Soto-Blanco B 2010: Serum protein electrophoretic profile of goats infected with Haemonchus contortus. Anim Vet Adv 9: 1603-1606

Eckersall PD 2008: Proteins, proteomics and the dysproteinemias. In: Kaneko JJ, Harvey JW, Bruss ML (Eds): Clinical Biochemistry of Domestic Animals. $6^{\text {th }}$ edn. San Diego, pp. 117-155

Evans P, Halliwell B 2001: Micronutrients: oxidant/antioxidant status. Br J Nutr 85: 67-74

Fonteque JH, Kohayagawa A, Mattoso CRS, Lopes STA, Paes PRO, Cassetari ML, Langoni H 2010: Electrophoretic profile and concentration of immunoglobulins G (IgG) in blood serum of Saanen goats with experimental mastitis induced by Staphylococcus aureus supplemented with vitamin E. Pesq Vet Bras 30: $79-86$

Janků L, Pavlata L, Mišurová L', Filípek J, Pechová A, Dvořák R 2011: Levels of protein fractions in blood serum of periparturient goats. Acta Vet Brno 80: 185-190

Krajničáková M, Kováč G, Kostecký M, Valocký I, Maraček I, Šutiaková I, Lenhard L 2003: Selected clinicobiochemical parameters in the puerperal period of goats. B Vet I-Pulawy 47: 177-182

Krakowski L, Zdzisińska B 2007: Selected cytokines and acute phase proteins in heifers during ovarian cycle course and in different pregnancy periods. B Vet I-Pulawy 51: 31-36

Matthews J 2009: Diseases of the goat. $3^{\text {th }}$ edn. Chelmsford, 434 p.

Murata H, Shimada N, Yoshioka M 2004: Current research on acute phase proteins in veterinary diagnosis: an overview. Vet J 168: 24-40

Nagy O, Tóthová C, Kováč G 2014a: Age-related changes in the concentrations of serum proteins in calves. J Appl Anim Res 42: 451-458

Nagy O, Tóthová C, Nagyová V, Kováč G, Pošivák J 2014b: Changes in the serum protein electrophoretic pattern in lambs during the first month of life. Acta Vet Brno 83: 187-193

Nagy O, Tóthová C, Nagyová V, Kováč G 2015: Comparison of serum protein electrophoretic pattern in cows and small ruminants. Acta Vet Brno 84: 187-195

NRC (National Research Council), 2007: Nutrient Requirements of Small Ruminants: Sheep, Goats, Cervids, and New World Camelids. National Academies Press, Washington, DC, USA

Pavlata L, Chomát M, Pechová A, Dvořák R 2011: Impact of long-term supplementation of zinc and selenium on their content in blood and hair in goats. Vet Med-Czech 56: 63-74

Pavlata L, Podhorský A, Pechová A, Chomát P 2005: Differences in the occurrence of selenium, copper and zinc deficiencies in dairy cows, calves, heifers and bulls. Vet Med-Czech 50: 390-400

Pechová A, Mišurová L, Pavlata L, Dvořák R 2009: The influence of supplementation of different forms of zinc in goats on zinc concentration in blood plasma and milk. Biol Trace Elem Res 132: 112-121

Petersen HH, Nielsen JP, Heegaard PM 2004: Application of acute phase protein measurements in veterinary clinical chemistry. Vet Res 35: 163-187

Piccione G, Casella S, Lutri L, Vazzana I, Ferrantelli V, Caola G 2010: Reference values for some haematological, haematochemical, and electrophoretic parameters in the Girgentana goat. Turk J Vet Anim Sci 34: 197-204

Piccione G, Messina V, Gianneto C, Casella S, Assenza A, Fazio F 2011a: Seasonal variations of the serum proteins in sheep and goats. Arch Tierzucht 4: 399-405

Piccione G, Messina V, Marafioti S, Casella S, Giannetto C, Fazio F 2012: Changes of some haematochemical parameters in dairy cows during late gestation, post partum, lactation and dry periods. Vet Med Zoot 58: $59-64$

Piccione G, Sciano S, Messina V, Casella S, Zumbo A 2011b: Changes in serum total protein fractions and albumin - globulin ratio during neonatal period in goat kids and their mothers after parturition. Annals of Anim Sci 11: $251-260$

Pyörälä S 2000: Hirvonen's thesis on acute phase response in dairy cattle. Helsinki, University of Helsinki, Faculty of Veterinary Medicine, $80 \mathrm{p}$.

Santarosa KT, Silva RCRE, Silva JBA, Soto-Blanco B 2005: Reference values for electrophoresis of serum proteins in goats. Arch Vet Sci 10: 46-48

Sevelius E, Andersson M 1995: Serum protein electrophoresis as a prognostic marker of chronic liver disease in dogs. Vet Rec 137: 663-667

Shaffer L, Roussel JD, Koonce KL 1981: Effect of age, temperature - season and breed on blood characteristics of dairy cattle. J Dairy Sci 64: 62-70

Strnadová P, Svobodová V, Pavlata L, Mišurová L, Dvořák R 2011: Effect of inorganic and organic zinc supplementation on coccidial infections in goats kids. Acta Vet Brno 80: 131-137

Thomas JS 2006: Overview of plasma proteins. In: Schalms Veterinary Hematology, Feldman BF, Zinkl JG, Jain NC (Eds) $5^{\text {th }}$ edn. Blackwell Publishing, Ames, pp. 891-898

Tóthová C, Kováč G 2009: Acute phase proteins in pigs (in Slovak). Veterinářství 59: 225-229

Tóthová C, Nagy O, Kováč G 2014: Changes in the concentrations of serum protein fractions in calves with age and nutrition. Ital J Anim Sci 13: 107-111

Tóthová C, Nagy O, Seidel H, Kováč G 2012a: The effect of storage temperature and time on the concentrations of major bovine acute phase proteins. Vet Med Int 1: 1-7 
Tóthová C, Nagy O, Seidel H, Kováč G 2012b: The effect of chronic respiratory diseases in calves on the serum protein electrophoretic pattern. Acta Vet Brno 81: 365-370

Tóthová, C, Nagy O, Seidel H, Kováč G. 2013: Serum protein electrophoretic pattern in clinically healthy calves and cows determined by agarose gel electrophoresis. Comp Clin Pathol 22: 15-20 